\title{
Monitoring Pesticide Residues in Surface and Ground Water in Hungary: Surveys in 1990-2015
}

\author{
András Székács, Mária Mörtl, and Béla Darvas \\ Agro-Environmental Research Institute, National Agricultural Research and Innovation Centre, Herman O. u. 15, \\ Budapest 1022, Hungary \\ Correspondence should be addressed to András Székács; a.szekacs@cfri.hu
}

Received 21 May 2015; Accepted 12 July 2015

Academic Editor: Athanasios Katsoyiannis

Copyright (C) 2015 András Székács et al. This is an open access article distributed under the Creative Commons Attribution License, which permits unrestricted use, distribution, and reproduction in any medium, provided the original work is properly cited.

Over 2000 surface, ground and raw drinking water samples have been analyzed in the frame of different monitoring projects in Hungary and watercourses in neighboring countries between 1990 and 2015. Effects of pesticide contamination on ecological farming and drinking water supply have been assessed. Main water pollutant ingredients of agricultural origin in Hungary are herbicides related to maize production. After EU pesticide re-registration, diazinon, atrazine, and trifluralin gradually disappeared as contaminants. High levels of water soluble pollutants (e.g., acetochlor) in surface water result in temporarily enhanced levels in raw drinking water as well. Extreme levels observed for herbicide residues were of agrochemical industrial origin.

\section{Introduction}

The widespread use of pesticides for agricultural and nonagricultural purposes has resulted in the presence of their residues in surface and ground water resources. The physicochemical properties of pesticide compounds, particularly their solubility in water and organic solvents, characterized by their octanol-water partition coefficients, determine their character of leaching into surface and ground waters [1]. Depending on their chemical stability, these substances may undergo decomposition processes; therefore, not only active ingredients but their metabolites may also occur as contaminants [2-4]. Most pesticides released into the environment are regarded as toxic substances, and newly emerging toxicological interactions have also been identified (mutagenicity, carcinogenicity, hormone modulant effects of environmental endocrine disruptor chemicals (EDCs), immunomodulant effects). Unfortunately not only pesticide residues but also other organic micropollutants (pharmaceuticals, personal care products, etc.) deteriorate water quality. Surfactants are common additives in agrochemical formulations to improve water solubility and uptake of the active ingredient and enhance its pesticide efficacy. Residues of surfactants are often detected in the environment; thus they can influence the effect of pesticide active ingredients. Recent studies indicate that combined toxicity of pesticide residues with other chemicals in agricultural use (e.g., adjuvants, detergents) has to be considered.

Contamination occurs not only due to current use of agrochemicals but also due to leaching of persistent ingredients from soil. Pesticide contamination of surface water in a particular region depends on several factors, such as closeness of crop fields to surface water, characteristics of surrounding fields (soil, grassland, slope, and distance to water bodies), and climate conditions (temperature, humidity, wind, and precipitation). In consequence, pesticide residues are being reported as common organic contaminants worldwide in surface waters and other environmental matrices [57]. Yet, pesticide residues may originate from urban pesticide application (e.g., roads, rails, urban, and family gardens): pesticides coming from urban areas are estimated to be responsible for as high as $30-50 \%$ of the total annual load. According to a study [8] the load of glyphosate from urban drainage system during rain events can exceed amounts of this herbicide originated from agricultural areas. Fast runoff from hard surfaces (e.g., urban roads) can lead to a fast increase of concentration shortly after the beginning of rainfall as it has been reported for glyphosate [8]. 
The presence of pesticides in water is regulated through different directives, including the Ground Water Directive [9], the Drinking Water Directive [10] and the Water Framework Directive [11], modified later several times [12, 13], setting a maximum concentration of $100 \mathrm{ng} / \mathrm{L}$ for individual pesticides and their degradation products, and $500 \mathrm{ng} / \mathrm{L}$ for total pesticide residues present in a sample. Currently environmental quality standards (EQSs) exist for 45 compounds or groups of compounds. There were also extensive programs to monitor water status of in European rivers and in ground waters which focused mainly on polar organic persistent pollutants $[14,15]$. The need for reliable analytical methods for monitoring chemical pollutants in surface water under the European Water Framework Directive [11] was reviewed in 2009 [16].

In the field of pesticide residue monitoring, multiresidue methods allow simultaneous determination of diverse classes of ingredients (e.g., organophosphorus and organochlorine pesticides, pyrethroids, triazines, phenoxycarboxylic acids, chloroacetamides, triazoles, certain (thio)carbamates, etc.) in a single analytical procedure involving sample preparation and usually gas chromatographic (GC) separation followed by a selective detection method. A main advantage of mass spectrometry (MS) for detection is that by providing structural information it enables identification of the analytes, therefore, the application of MS detection coupled to chromatography spread rapidly. As GC measurements are limited to volatile, thermally stabile compounds, these methods are not suitable for detection of more polar and/or thermally labile ingredients belonging to other pesticide classes (phenylureas, carbamates, neonicotinoids, benzimidazoles, etc.), and therefore, these commonly used pesticides have only recently included in water quality control by high performance liquid chromatography (HPLC) coupled to MS. Appropriate ionization techniques allow identification and quantification of a broad range of pesticide pollutants (e.g., triazines and chloroacetanilides). For nonpolar compounds GC-MS remained the method of choice.

Determination of certain ingredients requires single methods. For example, detection of glyphosate, currently the most widely applied herbicide active ingredient, and its major metabolite aminomethylphosphonic acid (AMPA) is a challenging task. Due to its good water solubility its extraction from water is difficult and its low detectability often has to be enhanced by derivatization. Despite of numerous analytical procedures published in the literature, determination of glyphosate is often missing from monitoring schedules. For glyphosate, only most recent LC tandem MS methods using electrospray ionization (LC-ESI-MS/MS) meet the Maximum Residue Level (MRL) by the EU for pesticide residues in drinking water [10], but the instrumentation demands of these methods are substantial. In contrast to these labor-intensive analytical procedures, enzyme-linked immunosorbent assays (ELISAs) allow selective and sensitive determination of glyphosate without sample preparation, but in these procedures AMPA is not detected. Due to difficulties in analysis large scale monitoring of glyphosate residues are seldom reported.
1.1. Pesticide Contamination Status in Surface Water in Hungary. Pesticide contamination presents a risk to the drinking (raw and tap) water supply and poses a problem via irrigation to ecological agriculture hindering pesticide-free farming. As the proportion of water wells obtaining raw drinking water from surface water resources is high in Hungary, especially in the region of Miskolc and along river Danube, the presence of pesticide residues in surface water bodies involves the risk of contamination of drinking water. The efficacy of pebble filtration on removal of microbial and organic micropollutants is low and effects of subsequent steps in classical drinking water treatments (e.g., chlorination, ozonization, and irradiation) do not effectively remove these pollutants. Persistent residues in soil exert their effects for long periods, and pesticides in surface and ground water may result in unintended exposure to residues through irrigation water.

Although surface water is regularly monitored for pesticides since 1976 in Hungary [17], earlier data are generally poor, and numbers of target compounds included were low. At the very beginning only some of persistent organic pollutants (POPs, e.g., organochlorine compounds) were regarded as problematic substances, in addition certain selected triazine, organophosphate, and chlorophenoxy acid type compounds were only involved in the monitoring schedule. At that time surface water analysis for residues mainly focused on compounds belonging to one or two different classes of pesticides that are amenable to GC. Later chloroacetanilides were also included, but some compounds were still omitted. Before long, given active ingredients (e.g., atrazine) proved to be persistent under certain conditions and occurrence of often applied water soluble ingredients (e.g., acetochlor) has also been observed [17]. The Hungarian Plant Protection Service has analyzed about 2000 surface water samples between 1994 and 2000 and found 5-50\% of the samples containing pesticide residues. Atrazine was the most frequently found water contaminant that was detected in $6 \%$ of samples at levels of $\sim 100 \mathrm{ng} / \mathrm{L}$. It was followed by acetochlor, another herbicide active ingredient applied for corn crops: $4 \%$ of water samples contained acetochlor. Diazinon and hexachlorocyclohexane $(\mathrm{HCH})$ were often determined at low concentrations. Propisochlor and metolachlor occurred less frequently, but their maximum concentrations fell between 10 and $100 \mathrm{ng} / \mathrm{L}$.

The presence of plant protecting agents in raw drinking water was investigated by the end of the last century in Hungary [18]. Traces of pesticides have been detected especially in waterworks using surface and bank filtered water. About $44 \%$ of surface samples contained pesticide residue above limit of quantification and among these samples $13 \%$ exceeded the level of $100 \mathrm{ng} / \mathrm{L}$. This maximum concentration for individual pesticides and their degradation products present in the samples have been established by Directive 98/83/EC [10] on the quality of water intended for human consumption. Among pollutants low levels of diazinon, high levels of atrazine $(5700 \mathrm{ng} / \mathrm{L})$ and in a single case prometryn reaching the level of $3220 \mathrm{ng} / \mathrm{L}$ were found. Chlorophenoxy acid type herbicides (2,4-D, dichlorprop, MCPA) were also often detected (8$15 \%)$ at levels up to $680 \mathrm{ng} / \mathrm{L}$. These identified risk cases for 
drinking water led to temporary or permanent closure of certain water wells.

These early detection cases prompted us to take part in different monitoring projects launched in the last fifteen years to obtain information on extent and distribution of pesticide pollution in Hungary. At the beginning of our work about 400 pesticide active ingredients were authorized in Hungary, and then the number of registered pesticide active ingredients was drastically reduced upon the pesticide re-registration process with regulations on pesticide usage in the European Union (EU) in 2005. This paper summarizes the results of these monitoring projects on pesticide contamination in surface and ground water resources in urban and agricultural areas in Hungary.

\section{Experimental}

In this work, a total of 49 pesticide residues and degradation products, belonging to different chemical classes, were monitored in Hungary. Water samples have been collected in the frame of seven monitoring projects in over twenty sampling campaigns between 1990 and 2015. Each sampling campaign had defined objectives and corresponding sampling regimes. In certain sampling campaigns, soils on cultivation fields were also sampled. Selection of target pesticides was done on the basis of their use and persistency. Determination of the selected analytes was performed using solid phase extraction (SPE) of water samples (1000x concentration factor) followed by GC-MS with or without derivatization [19], while determination of neonicotinoid insecticides was carried out by HPLC and glyphosate was measured by ELISA [20].

2.1. GC Analysis. Analytical sample preparation and GCMS procedure was a multiresidue pesticide analysis method applied by survey authorities in Hungary [21] and modified and validated in our laboratory [22]. Acidic ingredients, for example, chlorophenoxy acid type herbicides, were eluted from graphitized carbon black SPE cartridges in a second fraction and were then subjected to derivatization to silyl esters using $t$-butyldimethylsilyl $N, N$-dimethylcarbamate as silylating agent and trifluoroacetic acid catalyst [19]. GC-MS analysis was performed on a Varian Saturn 2000 workstation equipped with a Varian CP 8200 autosampler (Varian Inc., Walnut Creek, CA, USA). Quantification of the selected pesticides was performed using matrix-matched calibration. The estimated values of the limits of detection (LODs) were in the range $0.4-5.5 \mathrm{ng} / \mathrm{L}$.

2.2. HPLC Analysis. Determinations of neonicotinoid type pesticide active ingredients were performed on Younglin YL9100 HPLC system equipped with YL9150 autosampler (Younglin Co., Anyang Korea). Compounds were separated on a C18 column (Agilent Extend-C18, $150 \mathrm{~mm} \times 4.6 \mathrm{~mm}$ i.d., $5 \mu \mathrm{m})$ equipped with an Agilent Guard column $(12.5 \mathrm{~mm}$ $\times 4.6 \mathrm{~mm}$ i.d., $5 \mu \mathrm{m}$ ) at 40 degrees. UV detector signals were recorded at $\lambda=252 \mathrm{~nm}$ and $\lambda=269 \mathrm{~nm}$. Eluent flow rate was $1.0 \mathrm{~mL} / \mathrm{min}$ during the isocratic elution until 8 minutes $(70: 30=\mathrm{A}: \mathrm{B}$ eluents, $\mathrm{A}=90 \%$ water: $10 \% \mathrm{MeOH}$, $\mathrm{B}=\mathrm{MeOH})$. External calibrations based on the results for standard solutions (Pestanal) were used for quantification. If low concentration ranges required, HPLC-MS/MS measurements were carried out on a Bruker AmaZon SL ion trap instrument (Bruker AXS GmbH, Karlsruhe, Germany) operated in the positive electrospray ionization mode, upon SPE preparation of samples. Retention times were $2.42 \mathrm{~min}$ for thiamethoxam and $3.38 \mathrm{~min}$ for its decomposition product, clothianidin. LOD determined with standard solutions and with UV detector lied at $10 \mu \mathrm{g} / \mathrm{L}$. External calibration based on the results obtained for 12 standard solutions in the range of concentrations between $10 \mu \mathrm{g} / \mathrm{L}$ and $150 \mathrm{mg} / \mathrm{L}$. Determinations obtained upon SPE (Sep-Pak C18) with standard solutions and with MS/MS detector allowed LODs of $4 \mathrm{ng} / \mathrm{L}$ for thiamethoxam and $17 \mathrm{ng} / \mathrm{L}$ for clothianidin. Calibration solutions were prepared from a stock solution by dilution with water.

2.3. ELISA. As desirable low LODs for glyphosate and AMPA were not achieved even after their labor-intensive extraction [23] followed by derivatization prior to GC-MS analysis, for determination of glyphosate in ground and surface water, an immunoanalytical method, the commercially available ELISA method (PN 500086) by Abraxis LLC (Warminster, PA, USA) [24], was applied. Measurements [20] were carried out in 96-well microtiter plates according to manufacturer instructions. Comparative results with LC-MS or LC-MS/MS $[25,26]$ demonstrated the reliability of this competitive ELISA method; therefore, we have used it in our monitoring studies. The main drawback of the method is that it does not detect AMPA; therefore, due to the fast decomposition of glyphosate its environmental occurrence can be underestimated. On the other hand a comparative study [27] has established that immunoassay overestimated glyphosate concentration in some cases and detected a trace level in a sample deemed uncontaminated by LC-MS/MS.

\section{Results}

3.1. Nationwide Survey of Pesticide Residues in Surface Water in Hungary. A national survey (Project OMFB 02193/1999; Monitoring of pesticide residues in surface and ground water, 1999-2002) was launched together with the National Service for Plant and Soil Protection (NSPSP) to assess chemical contamination levels in water bases in Hungary, to explore the points of vulnerability, and to identify pesticide residues in surface and ground water throughout the country. An additional aim was to inspect whether chemical loads on the environment decreased due to the introduction and implementation of integrated pest management (IPM) practices and the spread of ecological (organic) agriculture and to indicate whether pesticide contamination occur as point source or diffuse contaminants. Thus, 332 surface and raw drinking water samples were collected at 90 sites in Hungary (see Figure 1). The overall numbers of water samples collected and analyzed were 118, 119, and 95 in 2000, 2001, and 2002 , respectively. Among these samples 24, 16, and 11 were 


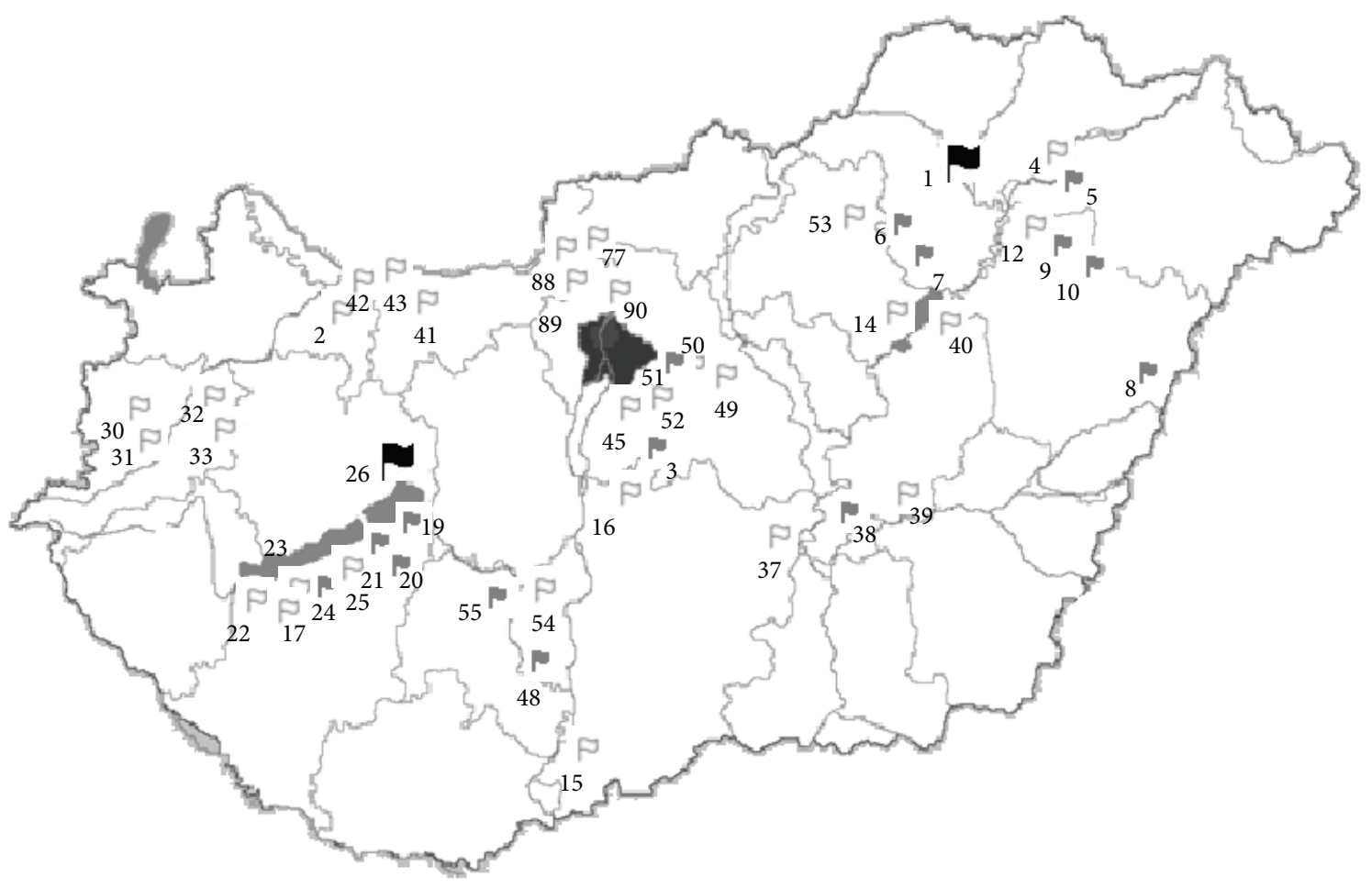

FIGURE 1: Sampling sites in the national survey between 1999 and 2002.

tap-water samples provided by Wedeco Waterworks Hungary or collected in the region of Vác in 2000-2002, respectively. In the first year of the survey (2000) $32 \%$ of water samples were found to be contaminated mainly by acetochlor and atrazine up to the level of $10000 \mathrm{ng} / \mathrm{L}$ (!) and prometryn have also been found at lower concentrations (1-10 ng/L). Two point contamination sources of industrial origin were identified in the region of Balatonfüzfö and the Northern Hungarian Chemical Works (Sajóecseg) (see Figure 1, sites 1 and 26). In 2001, 58\% of samples contained pesticide residues above the LODs. Earlier mentioned ingredients showed similar pattern; $36 \%$ of samples were polluted by atrazine and among them $3 \%$ are at concentrations above $1000 \mathrm{ng} / \mathrm{L}$, whereas the same ratios for acetochlor were $16 \%$ and $6 \%$. Thus, acetochlor occurred less frequently, but higher concentrations have been determined. Prometryn was found in $7 \%$ of the samples at levels of $100-10000 \mathrm{ng} / \mathrm{L}$. Among other pollutants trifluralin (10-10000 ng/L), metribuzin (100$1000 \mathrm{ng} / \mathrm{L})$, and terbutryn (10-1000 ng/L) were detected in 1$3 \%$ of samples. Although diazinon was often (36\%) found, its levels were usually low (10-100 ng/L). Regarding seasonal variation of residues it is worthy of note that one-third of samples polluted by atrazine and/or diazinon were collected prior to pesticide application, indicating persistency of these active ingredients under appropriate circumstances. The last year of the project (2002) focused on contaminated areas; therefore, $91 \%$ of collected samples contained one or more pesticide active compound. Maximum levels for atrazine and acetochlor remained high (over $15000 \mathrm{ng} / \mathrm{L}$ and $46000 \mathrm{ng} / \mathrm{L}$ ) and contamination rates for these ingredients were $44 \%$ and
$31 \%$, respectively. Prometryn was detected in $18 \%$ of samples up to $1270 \mathrm{ng} / \mathrm{L}$. Frequently found diazinon (65\%) at levels $10-100 \mathrm{ng} / \mathrm{L}$ and in 3\% of samples terbutryn (467-1671 ng/L) were determined.

Regarding raw drinking water samples there was only a single case when acetochlor has been detected during the first two years. However, in the autumn of 2002, acetochlor contamination in raw drinking water was observed in the region of Vác near river Danube. Its concentration in raw drinking water occurred to be near $100 \mathrm{ng} / \mathrm{L}$, sometimes exceeding the MRL for drinking water in the EU. To our surprise simultaneously collected surface water samples from river Danube contained similar concentration of this ingredient $(80 \mathrm{ng} / \mathrm{L})$. Acetochlor contamination of raw drinking water was also detected in Verőce (34-64 ng/L), but here the levels remained under MRL. As the contamination levels in the river were not extremely high, results indicated the pesticide content passed through bank filtration and water treatment (e.g., chlorination) and occurred at unmodified levels in tap water.

3.2. Assessment of Point Source Pesticide Contamination in Hungary. On the basis of results obtained in the nationwide survey, regions of identified point source contamination sites were monitored (Project KvVM-KAC; Revision of pesticide active ingredients regarding environmental assessment and monitoring results, 2003). Sampling was carried out mainly near Lake Velence and in two regions of Lake Balaton (Balatonfüzfö and Tihany). This project, supported by the Hungarian Ministry of Environment and Water, was also 
connected to the revision of pesticides considering environmental aspects and pesticide residue monitoring data. In the region of Balatonfüzfö extensive sampling was performed (62 samples) in order to assess the extent and severity of earlier detected point source contamination of industrial origin. Additional 21 sites at Lake Balaton, 14 sites at Lake Velence, and 11 sites in Budapest and other regions were sampled. Surface and raw drinking water samples were collected at 80 sites in May and at 28 additional sites in June and August, 2003. Sampling was repeated at polluted sites in June and/or August. Thus, overall 135 surface and raw drinking water samples were analyzed during the project.

The contamination rate was found to be as high as $61 \%$, and in accordance with earlier results, surface water samples collected in the region of Balatonfüzfö contained high or extremely high levels of atrazine and acetochlor. Maximum concentration of atrazine was $8240 \mathrm{ng} / \mathrm{L}$ and $7540 \mathrm{ng} / \mathrm{L}$ in surface water and ground water, respectively. The corresponding values for acetochlor were found to be $13950 \mathrm{ng} / \mathrm{L}$ and $10070 \mathrm{ng} / \mathrm{L}$, respectively. In addition, acetochlor could be measured in $56 \%$ of the tap water samples reaching the level $1075 \mathrm{ng} / \mathrm{L}$. Lower levels of prometryn (up to $1025 \mathrm{ng} / \mathrm{L}$ ) and terbutryn (up to $605 \mathrm{ng} / \mathrm{L}$ ) have also been found. The quality of effluent waters originated from the industrial site of Nitrokémia Chemicals Works was of high concern, as contaminated water bodies flow through basins and ponds into stream Séd and then reach Lake Balaton. Concentrations of atrazine and/or acetochlor in these water courses were in the range of 2000-6000 ng/L, and sometimes exceeded the level of $10000 \mathrm{ng} / \mathrm{L}$. Additional 18 sites in the neighborhood showed higher levels for acetochlor probably due to its leaching from contaminated soil around the area of Nitrokémia Works.

Atrazine was not detected and diazinon occurred in a single case at a level of $538 \mathrm{ng} / \mathrm{L}$. In the region of Tihany, the highest concentration was found to be $424 \mathrm{ng} / \mathrm{L}$ in surface water, $359 \mathrm{ng} / \mathrm{L}$ in Lake Balaton, and unfortunately appeared in a drinking water sample at a level of $249 \mathrm{ng} / \mathrm{L}$ (Csopak). South from the point contamination source half of samples from Lake Balaton were contaminated by acetochlor reaching the maximum concentration of $1547 \mathrm{ng} / \mathrm{L}$, whereas $332 \mathrm{ng} / \mathrm{L}$ was measured in Channel Sió. A similar pattern was observed at Lake Velence: $316 \mathrm{ng} / \mathrm{L}$ was determined in a surface water sample, whereas high contamination rates $(88 \%)$ were observed in the lake itself with levels up to $702 \mathrm{ng} / \mathrm{L}$ and $2970 \mathrm{ng} / \mathrm{L}$ as a peak concentration. Comparing the concentrations determined in water samples collected at a certain polluted site in May, July, and September, the levels of acetochlor, terbutryn, and prometryn ingredients decreased and similar tendency have been usually observed for levels of atrazine. High levels for atrazine and acetochlor have been detected due to improper technology applied for washing pesticide containers (Papkeszi).

More than half (56\%) of the raw drinking water samples collected in this polluted region near to Nitrokémia Works contained acetochlor above LOD. Contamination levels were in the range of 116 to $1075 \mathrm{ng} / \mathrm{L}$.
3.3. Pesticide Residues Monitored in Surface Water at Regions of Ecological (Organic) Agriculture. Due to the high level of diffuse pesticide contamination observed in the national survey, a separate monitoring study (Project OMFB-00947/2005; Methods for detection of persistent organic soil and water pollutants in ecological cultivation, 2006-2008) was focused on persistent organic pollutants (POPs) and their effects on ecological (organic) cultivation. Between 2006 and 2008, 115 water resources, used as source for irrigation of organic crops, have been investigated. Thus, surface water and soil samples collected in April-May, August, and October at ecological farming sites (see Figure 2) were analyzed for persistent pesticide residues. In 2006, eight organic farms were sampled; later investigations focused on polluted problem areas (Szarvas, Karcag, and Tamási). In the first year, 24 ground water and 46 surface water samples were collected that were used as irrigation water. In 2007 and 2008, only polluted sites were sampled $21+12$ surface and $6+6$ ground water samples were measured.

Among the nine water pollutant pesticides, the most often occurring ones were trifluralin, atrazine, lindane, diazinon, acetochlor, and metolachlor. Diazinon could be detected in $25-80 \%$ of the samples at levels below $50 \mathrm{ng} / \mathrm{L}$. About half of the samples contained atrazine $(<250 \mathrm{ng} / \mathrm{L})$ and/or trifluralin $(<50 \mathrm{ng} / \mathrm{L})$ ingredients. At two sites (Tamási and Karcag) high levels of atrazine $(100-250 \mathrm{ng} / \mathrm{mL})$ as point source contamination were detected probably due to drift from intensively cultivated field in the neighborhood.

In the second year, sampling focused on problem areas. Thus, surface and ground water samples were collected at three sites (Szarvas, Karcag, and Tamási). Three pollutants (trifluralin, lindane, and diazinon) were detected at low concentrations (5-15 ng/L) and traces of DDE ( $<3 \mathrm{ng} / \mathrm{L}$ ) occurred in a single case. To our surprise atrazine or acetochlor has not been observed.

In the third year four ingredients (trifluralin, atrazine, diazinon, and metolachlor) were found and contamination rate lied around $62 \%$. Contamination levels were between 1 and $20 \mathrm{ng} / \mathrm{L}$, except for atrazine, which was determined in five water samples at higher concentrations $(40-250 \mathrm{ng} / \mathrm{L})$. Acetochlor has not been observed. Absence indicates that no illegal use was found regarding this often occurring water pollutant. Due to their leaching from soil diazinon, atrazine and trifluralin are common water pollutants in Hungary. These soil disinfectants and herbicides could be detected in $28 \%, 38 \%$, and $48 \%$ of water samples, respectively.

In summary $56 \%, 28 \%$, and $62 \%$ of water samples collected in the frame of project were found to be polluted by one or more pesticide active ingredients in 2006, 2007, and 2008 , respectively. The same values for soils were $38 \%, 59 \%$, and $41 \%$, whereas the main soil pollutants were DDE, lindane, and trifluralin. Although surface water samples collected near ecological fields were not pesticide-free, residue levels found typically lower than that of intensively cultivated areas.

3.4. Comparison of Regional Pesticide Contamination in Intensive and Ecological (Organic) Agriculture. Levels of pesticide residues in surface water and soil are strongly related to 


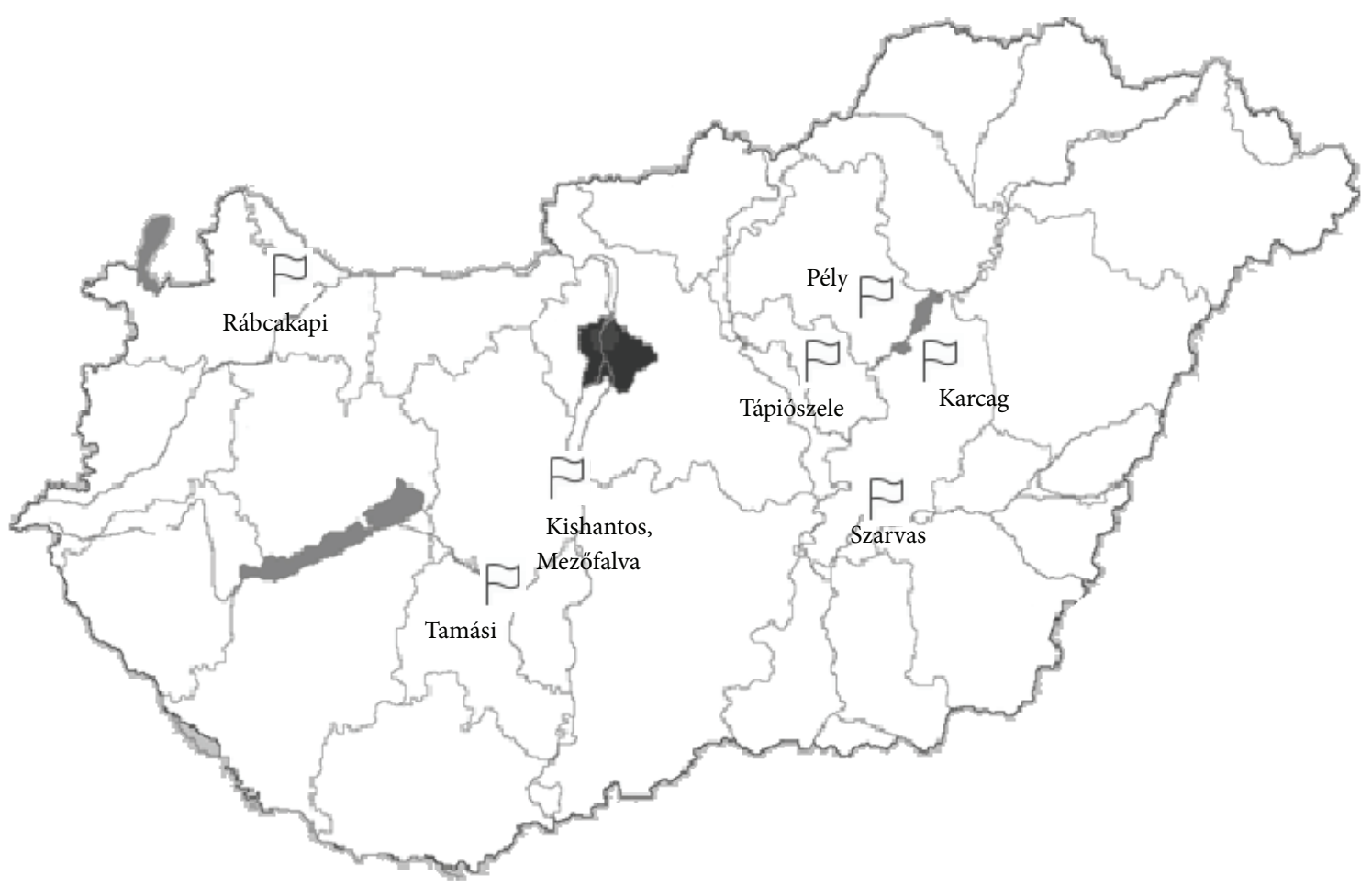

FIGURE 2: Surface water sampling sites near fields of ecological (organic) agricultural production (2006-2008).

each other: organic micropollutants in surface or irrigation water may be absorbed in soil layers, and vice versa, soil contaminants may leach into surface water. Aiming at developing an ecotoxicology based monitoring system for soil micropollutants (Project NKFP_07_A4-MONTABIO; Complex monitoring system for analytical detection and biological evaluation of soil micropollutants for a sustainable environment, 2008-2010), environmental samples from were comparatively surveyed among cultivation sites of intensive and ecological farming at a regional (county level) survey. Within the three-year sampling campaign, 286 surface and ground water samples (2008: 81, 2009: 121, 2010: 84) collected in Békés county, Hungary (see Figure 3), were analyzed. The survey also included statistical assessment of the reliability of the sampling techniques, as well as the biological evaluation of aquatic ecotoxicity. Regarding the 14 sampling sites five industrial fields, four ecological fields, four intensively cultivated fields, and a pasture have been involved.

The survey revealed extensive contamination of both surface water and soil. During the entire sampling campaign, 139 water samples contained detectable contamination by one or more target compounds (contamination rate $49 \%$ ). Acetochlor $(22-3900000 \mathrm{ng} / \mathrm{L})$ and diazinon $(1-851 \mathrm{n} / \mathrm{L})$ were the most frequently found water pollutants, metolachlor (1$56000 \mathrm{ng} / \mathrm{L})$ was often detected, and atrazine (500-10000 ng/ $\mathrm{L})$ and trifluralin (800-900 ng/L) also occurred in 2008 and 2009. Diazinon was found only in 2008, and traces of terbutryn were also detected in two samples in the first two years of the project. In 2010 diazinon (18-651 ng/L) occurred again and higher rate of samples contained the most often detected acetochlor (22-6250 ng/L). Acetochlor was detected in 61\% of contaminated water samples, $24 \%$ contained diazinon, $19 \%$ metolachlor, $16 \%$ atrazine, and $11 \%$ trifluralin. Some other ingredients (prometryn, dimethenamid, dimethirimol, and ethofumesate) occurred in 2-3\% of contaminated samples. One-quarter of the soil samples contained traces of DDT (the insecticide banned in Hungary first in the world in 1968) or its decomposition products. Due to their very low water solubility, these substances do not appear in surface and ground water samples, but other soil pollutants occur as water pollutants as well. Most common soil pollutants were trifluralin at concentrations of 1.0 to $1800 \mathrm{ng} / \mathrm{g}$ and acetochlor and metolachlor at lower levels.

In 2008, low amounts of precipitation resulted in higher contamination rate, and about $67 \%$ of water samples contained one or more pesticide active ingredients. In the next year only in $18 \%$ of water samples pesticide residue has been found. In 2010 sampling was performed only at sites where pesticide residues had been detected earlier; therefore, the contamination rate was understandably higher $(73 \%)$ than in previous years. About a quarter of the samples contained only low levels (below $50 \mathrm{ng} / \mathrm{L}$ ) of residues. Concentrations observed were similar to values measured in the previous year in accordance with high amounts of precipitation that was characteristic for both years. Pesticide residue levels were beyond the values set by Ground Water Directive [9]. Sixteen percent of samples exceeded the maximum concentration of $100 \mathrm{ng} / \mathrm{L}$ for individual pesticides, and in $10 \%$ of samples over $500 \mathrm{ng} / \mathrm{L}$ were total pesticides present as an average for three years. The same ratios were $32 \%$ and $12 \%$ in 2010 , respectively. 


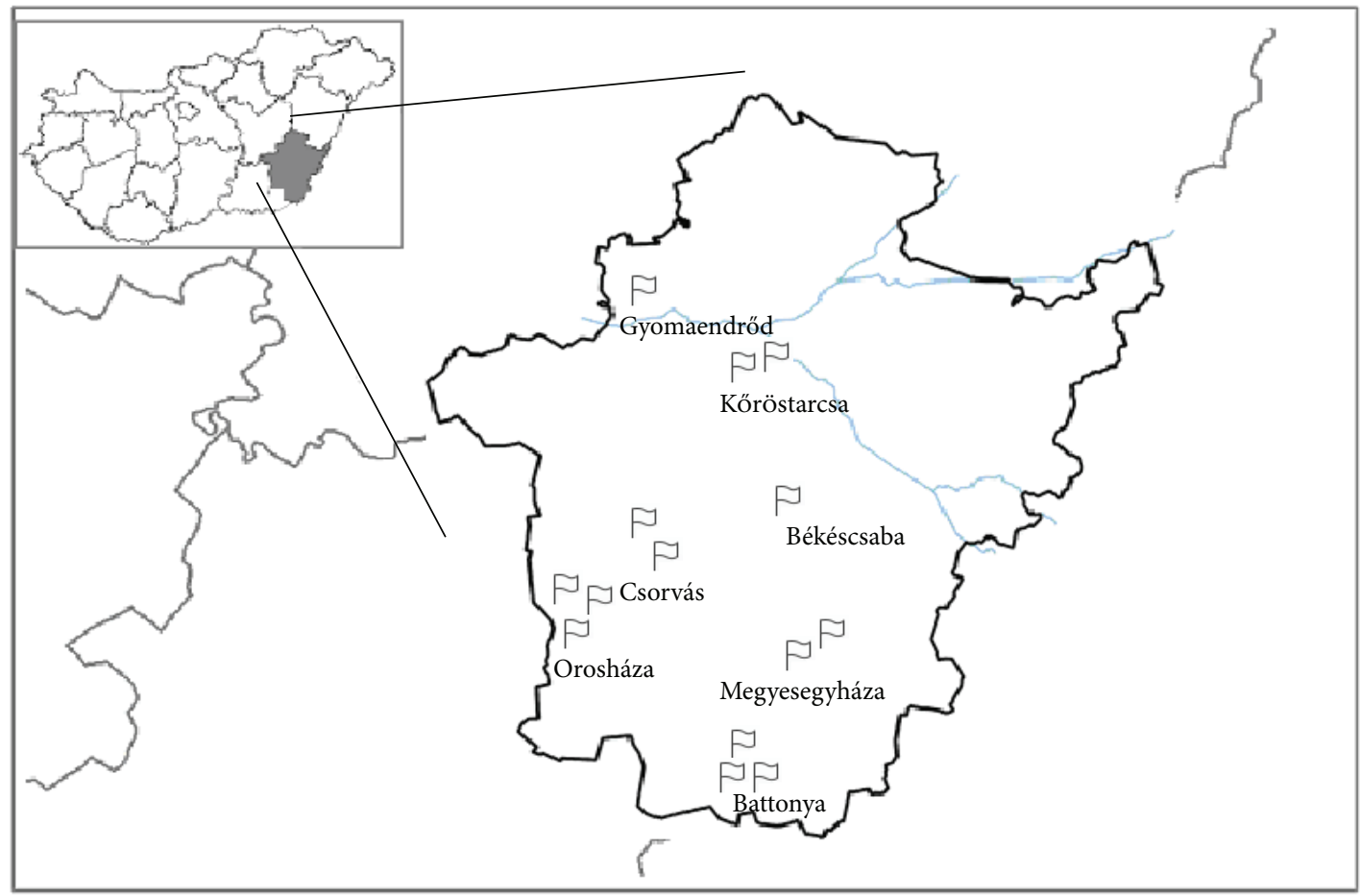

FIGURE 3: Surface and ground water sampling sites in Békés county (Hungary) (2006-2008).

Point source contamination due to illegal pesticide deposit was explored in the region of Gyomaendröd. Acetochlor, atrazine, and trifluralin were found in soil at alarmingly high concentrations (up to $590 \mathrm{ng} / \mathrm{g}, 632-782 \mathrm{ng} / \mathrm{g}$, and 1440-1882 ng/g). Ground water samples were also highly contaminated. For example acetochlor concentrations were in the range of $1870-6250 \mathrm{ng} / \mathrm{L}$, atrazine concentrations measured 465-4990 ng/L, and trifluralin also appeared as some other ingredients (terbutryn and metolachlor). In the last year of the project (2010), high amounts of ethofumesate were found in 3 water samples collected at Gyomaendrőd and 2 samples contained dimethenamid and dimethirimol. These pesticide active ingredients have not been detected earlier. Dimethenamid is a currently used chloroacetamide type herbicide, in contrast to dimethirimol which is a pyrimidinol type systemic fungicide banned in EU since 2002.

Half of water samples collected at industrial sites in Orosháza (County Public Road Service and glass factory) contained hydrocarbon contamination. Only acetochlor pesticide residue could be detected in water and due to high background in the organic layer no pesticide residues could be identified.

In the frame of the project a new derivatization technique was developed for the determination of chlorophenoxy acid type herbicides from water samples. This procedure was routinely applied for analysis of surface and ground water samples collected from Békés county in Hungary in the autumn of 2010. Nearly half of the water samples collected were affected by residues of 2,4-D (11-38 ng/L) above LOQ and it could be detected in $79 \%$ of the samples. In three highly contaminated samples amounts of 2,4-D (176, 907, and $1003 \mathrm{ng} / \mathrm{L}$ ) have been determined. Some other ingredients belonging to this group (mecoprop, MCPA, dichlorprop, MCPB) have also been detected in ten samples collected at sites Gyomaendröd and Orosháza county Public Road Service. 2,4,5-TP (fenoprop) has not been registered in Hungary and it is banned in the EU since 2004.

The concentration of glyphosate was also determined by ELISA method [24] in 42 surface and ground water samples collected from Békés county in Hungary. Half of the 42 surface and ground water samples collected in September 2010 were contaminated by glyphosate at concentrations of 540-980 ng/L. Exceedingly high glyphosate levels (nearly $1000 \mathrm{ng} / \mathrm{L}$ ) were measured in five ground water samples and significant concentrations (540-760 ng/L) were determined in 16 cases ( 3 surface and 13 ground water samples). Three ecological samples and two surface water samples from a pasture were also found to be contaminated.

In a similar survey carried out at cultivation sites of spice paprika, environmental and food safety aspects of spice paprika cultivation and production were investigated (Project EU-FP7-SEC-2012-1-312631; Securing the spices and herbs commodity chains in Europe against deliberate, accidental, or natural biological and chemical contamination (SPICED), 2014-2016). The environmental and food safety of spice paprika production is of key concern in spice production in Europe. As imported spice paprika commodities are often found contaminated by the EU Rapid Alert System for Food and Feed (RASFF), domestic spice paprika production is required to be assessed for organic micropollutants, and 


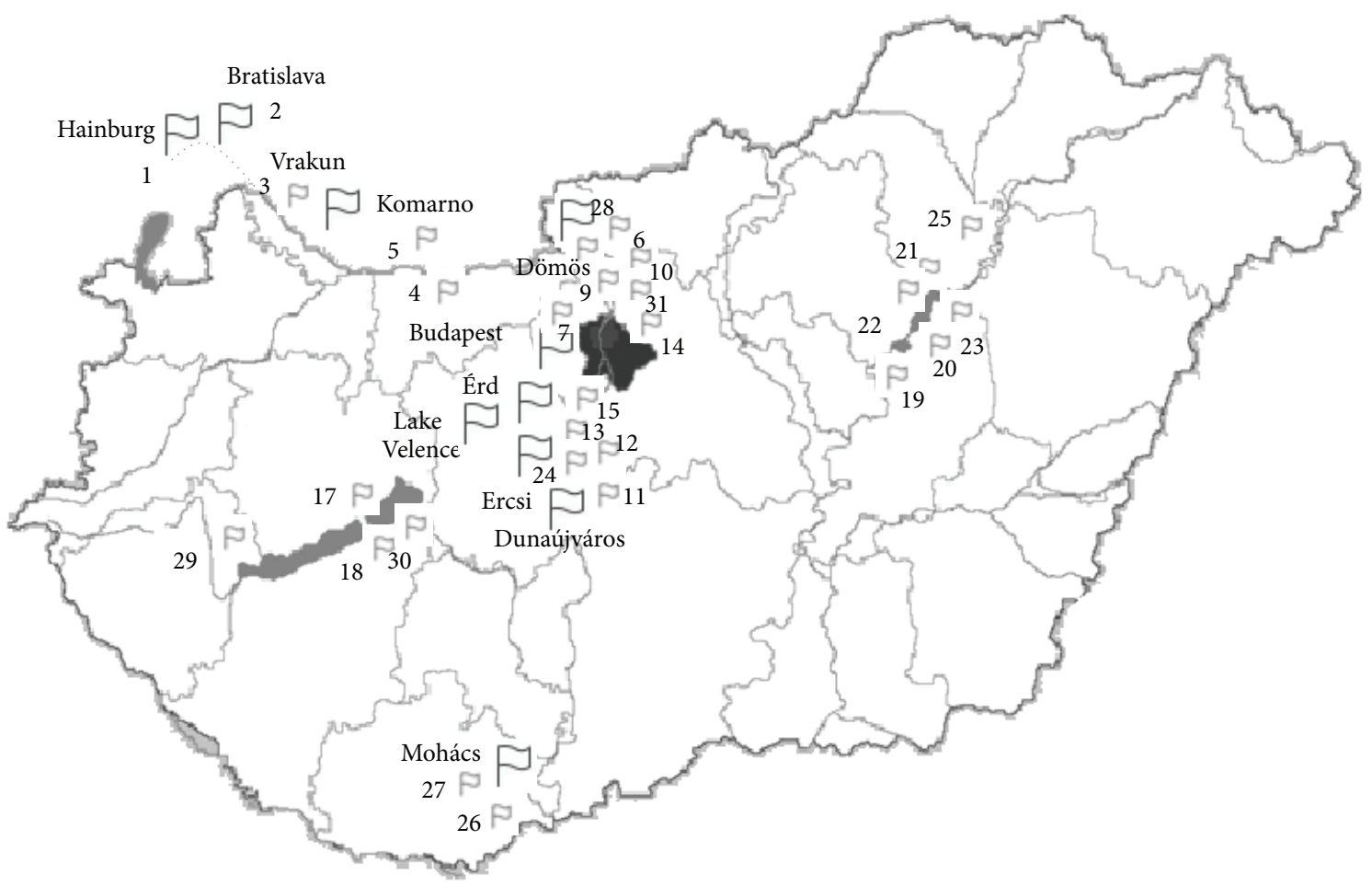

FIGURE 4: Surface water sampling sites along the Danube and throughout the country in 2011.

environmental pesticide residue contamination is also to be monitored. In field studies three different paprika producers ( 2 sites of each) practicing intensive cultivation mode and three organic farmers have been involved. Thus, 110 soil samples were collected in paprika cultivation fields at 9 locations, and 6 water samples near to fields have also been sampled that have been partly used for irrigation in each sampling regime (June and September). Soil contamination has been found only in samples collected from intensive cultivation fields. Trifluralin, tefluthrin, and DDT together with decomposition products (DDE and DDD) and in a single case chlorpyrifos were determined, whereas in some cases traces of diazinon and atrazine and in a single case metolachlor were detected but were not quantified. Trifluralin has been measured in $50 \%$ of water samples at levels $11-34 \mathrm{ng} / \mathrm{L}$. Half of soils collected at intensively cultivated sampling sites has been polluted by tefluthrin, one of the most toxic pyrethroids used against soil pests. Surface water samples collected there have not contained this ingredient probably due to its low water solubility. Although DDT and its metabolite (DDE) or degradation product (DDD) appeared at high levels in soil samples collected at two sites, due to their low water solubility they have not occurred in surface water nearby and or in paprika harvested from these intensively cultivated fields.

\subsection{Transnational Survey of Seasonal Pesticide Contamination} in Rivers in the Carpathian Basin. To assess the extent of pesticide contamination carried by rivers, in given cases through national frontiers (Project HUSK/0901/2.1.2/0076; Agrowater, 2011-2013), samples collected from Danube, Tisza and Vág rivers, streams, Lake Balaton, and other surface waters and some of drinking water samples were analyzed. Samples were collected in February 2011 before pesticide application along the Danube River, and the same sites from Hainburg (Austria) through Bratislava-Komarno (Slovakia) to numerous sampling points in Hungary, Mohács being the most Southern point, were revisited for repeated sampling after pesticide application during a one-month period after the middle of May. Other sites in the catchment area (Tisza, Balaton, and Vág) and tap water have also been sampled. Monitoring was conducted at eleven sampling sites along the river in the winter and at 31 sampling sites in the summer (see Figure 4). Monitoring continued in 2012 and 2013, but sampling has been restricted to Danube River (Budapest). Sixteen surface water samples from Danube and 12 tap water samples were taken twice a week in May and June and four additional samples from Lake Velence in the middle of June in 2012. Similar sample collection from Danube has been performed in 2013, but sometimes it had to be cancelled due to flood in the middle of June. Therefore only twelve samples were analyzed in that year.

All surface water samples contained traces of some pesticide residues (trifluralin, alachlor, and chlorophenoxy acids) in February indicating their slow degradation and dissipation rate. Withdrawn ingredient, alachlor, could be detected only in the winter sampling regime at low levels $(0.7-10.3 \mathrm{ng} / \mathrm{L})$. In the summer sampling regime (May-June) the ratio of surface water samples that exceeded the maximum concentration of $100 \mathrm{ng} / \mathrm{L}$ for individual pesticides was $41 \%$, and $18 \%$ of samples contained total pesticide residue above $500 \mathrm{ng} / \mathrm{L}$. Regarding the ingredients and the typical levels results were 
in accordance with those obtained for samples in Békés county earlier. Acetochlor was the most frequently found pollutant. It was present in all but one surface water samples collected in May and June and typically higher concentrations (75-711 ng/L) have been observed in May than in June (23$162 \mathrm{ng} / \mathrm{L})$. Metolachlor the second most frequently detected ingredient polluted $65 \%$ of samples collected and levels in Danube were $31-241 \mathrm{ng} / \mathrm{L}$. No special pattern for pollutants' concentrations could be observed along the river. Earlier often detected and banned persistent water pollutants also appeared in samples collected in May and June. Similarly to results found in 2011-2013, atrazine was detected in 13\% of samples at levels $17-40 \mathrm{ng} / \mathrm{L}$, in addition trifluralin $(25 \%$, $4-31 \mathrm{ng} / \mathrm{L})$ and ethofumesate $(19 \%, 12-27 \mathrm{ng} / \mathrm{L})$ also often occurred. Less frequently diazinon $(16 \%, 6-10 \mathrm{ng} / \mathrm{L})$ and prometryn (10\% 7-40 ng/L) were observed.

All but one drinking water samples contained acetochlor and it could be measured around the MRL for drinking water in EU $(100 \mathrm{ng} / \mathrm{L})$ in three tap water samples collected in May. In accordance with earlier results 2,4-D residues were often present, and $80 \%$ of samples contained it even in winter samples at levels of $0.24-3.81 \mathrm{ng} / \mathrm{L}$. Its amounts were the highest in samples collected in June (56-186 ng/L). Low levels of other chlorophenoxy acid type herbicides (mecoprop, dichlorprop, and MCPA) have also been detected but their amounts could be quantified only in two cases (6\%).

Samples were analyzed for glyphosate residues by the immunoanalytical method used previously [24]. It was applied for 18 surface water samples collected from the Danube River and Lake Velence in Hungary at 12 sampling sites in the middle of May 2011 and repeated at six sites along the Danube in October (see Figure 4). Glyphosate was detected only in a single sample collected at Lake Velence in May and in two samples from Danube in the autumn at levels near LOD, therefore, practically no contamination was found in 2011. Monitoring of glyphosate was restricted to Danube River at Budapest in 2012. Samples were taken twice a week in May and June from Danube and four additional samples from Lake Velence in the middle of June. Three of sixteen surface water from Danube contained glyphosate near LOD $(120 \mathrm{ng} / \mathrm{L})$, but in other cases presence of ingredient was detected. Levels (125-242 ng/L) were near LOD except for sample collected on 1st June, when $455 \mathrm{ng} / \mathrm{L}$ was measured. Similar contamination rate (75\%) was determined for samples from Lake Velence with levels near LOD (180-228 ng/L).

Results in 2014 and 2015 (Project AD006; Assessment of (bio)chemical, biological main and side-effects of organic microcontaminants of agricultural origin, monitoring, and determination in environmental and biological samples, 2014-2016) showed a similar pattern seen in 2011, but acetochlor the earlier most frequently found pollutant has not been observed, in contrast to metolachlor that was present in $75 \%$ surface water samples collected in May and June (45-365 ng/L). No special temporal variation in time for metolachlor concentrations could be observed. Atrazine could be detected in $13 \%$ of samples at levels $17-40 \mathrm{ng} / \mathrm{L}$, often occurred trifluralin $(25 \%, 4-31 \mathrm{ng} / \mathrm{L})$ and ethofumesate $(19 \%$, $12-27 \mathrm{ng} / \mathrm{L})$. Less frequently were observed diazinon (13\%, 6$10 \mathrm{ng} / \mathrm{L})$ and prometryn (6\% 7-40 ng/L).
The vast majority of surface water samples (92\%) contained neonicotinoids below LOD, while the highest concentrations $(10-41 \mu \mathrm{g} / \mathrm{L})$ were measured from temporary shallow water bodies after rain events in early summer. Only thiamethoxam and its decomposition product clothianidin were detected among neonicotinoids. These levels are in agreement with recent findings reported for neonicotinoids as surface water polluting contaminants [28-31].

3.6. Ecotoxicological Analysis. Given surface water contaminants were subjected to targeted ecotoxicological analysis. Thus, special emphasis was given the combined toxicity and ecotoxicity of glyphosate and its formulating adjuvants, as well as to distribution and ecotoxic effects of neonicotinoid active ingredients.

Although glyphosate presents lower acute toxicity than other herbicides, its widespread use and difficulties in detection [32] prompts cautious assessment for combination effects as well. It has been evidenced to cause toxicity and genotoxicity in aquatic organisms and amphibians [33] and teratogenicity in amphibians and birds [34] and has been shown to induce endocrine disrupting effects as well [35], the latter effect being highly synergized by polyethoxylated tallowamine (POEA) and other commonly used formulating agents in glyphosate-based herbicide preparations. As an immediate consequence of the above toxicological and ecotoxicological concerns and as these substances have proven to be persistent under typical application conditions [36], glyphosate and its metabolite AMPA are required to be regularly monitored in surface and ground waters. Combinational ecotoxicological effects were proven in our hands as well, on various aquatic organisms $[37,38]$. Moreover, adjuvant enhanced cytotoxicity has been evidenced on cell lines of animal [39] and human [40] origin.

Our preliminary results indicate that a newly emerging pesticide class of neonicotinoids can be found in environmental water samples as well. Sporadically clothianidin was found in ponds near to maize and sunflower crops emerged from treated seeds. These compounds are used mainly as seed dressings, and the portions not uptaken by target crops contaminate the environment. They accumulate in soil [41] and due to their good water solubility they appear in water resources. As neonicotinoids exert systemic action, the active compounds are translocated and distributed throughout the entire plant; therefore, consumption of different parts of plants (pollen, nectar) could be harmful to insects. Novel ways of intoxication for bees have also been explored, that is, water collection from guttation liquid [42]. They appeared in potatoes [43] and high contamination rates were reported for fruits and vegetables, as well as honey samples [44]. Serious bee poisoning events and risk assessment of EFSA in January 2013 led the European Commission to the conclusion [45] that a high risk for bees cannot be excluded except by imposing further restrictions for two years involving withdrawal of authorization of neonicotinoids and ban of treated seeds for different crops. The restriction applies to the use of 3 neonicotinoid active ingredients (clothianidin, imidacloprid, and thiamethoxam) for seed treatment, soil 
application (granules), and foliar treatment on crops attractive to bees, including certain cereals. Our findings prompted us to expand our investigations to these target compounds as well as to other polar pollutants amenable only by LC-MS analysis.

\section{Discussion}

Pesticides residues in surface waters have routinely been detected in nationwide studies [17-22]. The rate of contaminated (detectable) samples ranged between 2 and 51\%. In the period of 1994-2000, the most common contaminants were atrazine $(6 \%)$, acetochlor $(4 \%)$, propisochlor $(1.5 \%)$, metolachlor (1.5\%), diazinon (1\%), and 2,4-D (1\%). Key contaminants were atrazine and to some extent isoproturon, being found in several cases at above $100000 \mathrm{ng} / \mathrm{L}$. Results of the national survey between 1999 and 2002 and other studies on problem areas also indicated diffuse contamination of surface and ground water in Hungary. Surprisingly high contamination rate, 32-61\%, was found in monitoring projects. Concentrations of various pesticide active ingredients and metabolites investigated in surface water and raw drinking water, along with their MS identification descriptors, are presented in Table 1.

Two point contamination sources of industrial origin were identified in the region of Balatonfüzfö (Nitrokémia Chemicals Works) and Sajóecseg (Northern Hungarian Chemical Works) connected to former pesticide producers. Atrazine and acetochlor were found in soils in Balatonfüzfö (Nitrokémia Ipartelepek) at alarmingly high concentrations reaching 10-400 ng/g; therefore, the levels of these ingredients in surface waters in surroundings, for example, in the Séd stream, exceeded the level of $10000 \mathrm{ng} / \mathrm{mL}$. Extremely high levels were measured around Sajóecseg not only for acetochlor, but occasionally concentrations for atrazine, prometryn, and terbutryn were above $1000 \mathrm{ng} / \mathrm{L}$ in the same sample [22]. Sometimes concentrations in soil were as high as ingredient content in formulated pesticides. At these sites due to exceedingly high residue levels phytoremediation is impossible. Point contamination source due to illegal pesticide deposit has also been explored in Gyomaendrőd. Apart from these extremities typically more than half of surface and ground water samples contained one or more pesticide active ingredient.

Temporal alterations of residue concentrations have been characterized by bimodal pattern. Whereas pesticide contamination in soil samples appeared to be more uniform in time, contamination rates and levels in water are time dependent. As amounts of precipitation strongly influence leaching of pesticides, levels determined depend not only on pesticide application, but also on meteorological conditions. As expected, the highest levels of pesticide pollution appeared in water samples collected in late spring and autumn campaigns but rarely occurred in waters sampled in August.

Although high contamination rates have been found, but due to the improvements of analytical methods, low LODs can be achieved for most target compounds and trace levels of contaminants are detected. One of the minimum performance criteria for analytical methods applied for monitoring chemical pollutants corresponds to the limit of quantification (LOQ) According to the WFD, LOQs should be equal or less than $30 \%$ of the relevant Environmental Quality Standards (EQSs) [16]. Legally only concentrations measured above the MRL are significant and samples containing pollution below the MRL are regarded as pesticide-free by authorities. Independently from toxicological considerations for individual ingredients, MRLs for pesticide residues in drinking water and ground water in the EU have been set to a common standard value (100 ng/L). Directive 2013/39/EU [13] proposed maximum allowable concentrations (MAC) and annual average (AA) for levels of priority compounds and certain other pollutants in inland surface and other surface waters as EQSs. Values were set for a number of pesticides including alachlor, atrazine, simazine, diuron, isoproturon, chlorfenvinphos, chlorpyrifos, endosulfan, trifluralin, hexachlorocyclohexanes (HCHs), DDT, aldrin, dieldrin, endrin, and isodrin [12]. MAC values for some of detected water pollutants in Hungary are $700 \mathrm{ng} / \mathrm{L}$ and $2000 \mathrm{ng} / \mathrm{L}$ for alachlor and atrazine, respectively, but for trifluralin no MAC value is applicable. In our surveys, these levels have rarely been exceeded, only in the cases of point contaminations, where higher concentrations were determined for atrazine. In contrast to the above mentioned limits, pesticide-free means zero level of residues for the public, and it is often a source of confusion or contradiction between the authorities and civil society.

Pesticide application adversely influences the quality of surface water supplies, especially when water soluble ingredients are used. High levels of pesticide in surface water can lead to their occurrence in raw drinking water. According to a survey related to drinking waters published in 1998 [18], the levels of atrazine, diazinon, and prometryn in subsurface water exceeded the MRL by the corresponding harmonized EC Directive [9], effective in Hungary as well, set to $100 \mathrm{ng} / \mathrm{L}$ for residues of a given pesticide and $500 \mathrm{ng} / \mathrm{L}$ for all pesticide residues in driknking water. Our investigations explored vulnerable points of drinking water supply along the Danube and confirmed these earlier detections. Due to insufficient efficiency of bank filtration in certain cases, pesticide residues may contaminate raw drinking waters. Our investigations in 2002 indicated tap water pollution by acetochlor concerned to the most vulnerable water resource, namely, to pebble filtration wells in the region of Vác nearby river Danube. Similar contamination was found earlier in Island Buki [18] near to these sites, where the drinking water well has been closed and as we reported, contamination repeatedly occurred in 2011 as well.

Another important issue is to avoid or minimize pesticide contamination in ecological cultivation. Organic farming is not free from pesticide residues because of (i) drift, leaching from fields treated with agrochemicals nearby; (ii) pesticide residues in irrigation water; (iii) persistent pollutants from treatments prior to organic cultivation; (iv) illegal pesticide application. We have observed that pesticide contamination levels determined in organically cultivated fields are on the average one order of magnitude lower than in intensively cultivated fields. 
TABLE 1: Target compounds, their chromatographic retention time, and characteristic molecule ions for MS identification and concentrations found in surface water samples.

\begin{tabular}{|c|c|c|c|c|}
\hline $\begin{array}{l}\text { Pesticide active } \\
\text { ingredient/metabolite }\end{array}$ & $\begin{array}{l}\text { Retention } \\
\text { times } \\
(\min )\end{array}$ & $\begin{array}{l}\text { Quantitation ion } \\
\text { (other ions) }(m / z)\end{array}$ & $\begin{array}{l}\text { Concentration } \\
\text { range as diffuse } \\
\text { contaminant }(\mathrm{ng} / \mathrm{L})\end{array}$ & Comment \\
\hline \multicolumn{5}{|c|}{ GC analysis } \\
\hline \multicolumn{5}{|c|}{ Neutral and basic substances } \\
\hline Propachlor & 10.075 & $120(176,212)$ & - & \\
\hline Trifluralin & 10.817 & $306(264,290)$ & $800-10000$ & Soil contaminant as well \\
\hline Phorate & 11.038 & $121(75,231,260)$ & - & \\
\hline Simazine & 11.490 & $201(173,186)$ & - & \\
\hline Atrazine & 11.651 & $200(215,216)$ & $500-15000$ & $\begin{array}{l}>15600 \mathrm{ng} / \mathrm{L} \text { (in } 2002 \text { ) as point source; } \\
\text { soil contaminant as well }\end{array}$ \\
\hline Lindane & 11.888 & $181(183,217)$ & $5-15$ & Soil contaminant \\
\hline Terbuthylazine & 11.910 & $214(173,229)$ & - & \\
\hline Diazinon & 12.183 & $179+137(152)$ & $10-900$ & Soil contaminant as well \\
\hline Tefluthrin & 12.301 & $177(197,141)$ & - & Soil contaminant \\
\hline Pirimicarb & 12.690 & $166(239,72)$ & - & \\
\hline DDMS & 12.925 & $235(237,199)$ & - & \\
\hline Dimethenamid & 13.000 & $154(230,203)$ & traces & \\
\hline Dimethachlor & 13.007 & $134(197,210)$ & - & \\
\hline Metribuzin & 13.070 & $198(57,199)$ & $100-1000$ & \\
\hline Acetochlor & 13.139 & $224(223,174)$ & $20-6300$ & $\begin{array}{l}46000 \mathrm{ng} / \mathrm{L} \text { (in } 2002 \text { ) and } 3900000 \mathrm{ng} / \mathrm{L} \\
\text { (in } 2008 \text { ) as point source; soil } \\
\text { contaminant as well }\end{array}$ \\
\hline Heptachlor & 13.305 & $272(274,100)$ & - & \\
\hline Alachlor & 13.345 & $188+238(160)$ & $1-10$ & \\
\hline Prometryn & 13.364 & $241(242,184)$ & $100-10000$ & $>6100$ ng/L (in 2003) \\
\hline Dimethirimol & 11.420 & $166(209)$ & traces & $>100 \mathrm{ng} / \mathrm{L}$ in a single instance (in 2010) \\
\hline Propisochlor & 13.451 & $224,162(223)$ & $10-100$ & \\
\hline Terbutryn & 13.624 & $185(242,226)$ & $10-1000$ & $>83800$ ng/L (in 2003) \\
\hline Ethofumesate & 13.761 & $207+161(286)$ & $10-30$ & \\
\hline Malathion & 13.871 & $173(127,125)$ & - & \\
\hline Aldrin-R & 13.990 & $293(66,293,65)$ & - & \\
\hline Metolachlor & 14.049 & $162(238,240)$ & $1-56000$ & Soil contaminant as well \\
\hline Chlorpyrifos & 14.070 & $314(316,258)$ & - & Soil contaminant \\
\hline Triadimenol & 14.900 & $168(128,71)$ & traces & \\
\hline Penconazole & 14.700 & $248(159,251)$ & - & \\
\hline Pendimethalin & 14.710 & $252(282,253)$ & - & \\
\hline Heptachlor Epoxide & 14.775 & $353(355,351)$ & - & \\
\hline Endosulfan & 15.490 & $195(339,160)$ & - & \\
\hline Hexaconazole & 15.700 & $214(111,97)$ & - & \\
\hline $\mathrm{DDE}$ & 15.865 & $318(208,282)$ & $<3$ & Soil contaminant \\
\hline DDD & 16.907 & $235(237,207)$ & - & Soil contaminant \\
\hline Dieldrin & 16.059 & $79(79,81,277)$ & - & \\
\hline Endrin & 16.617 & $279(243,245)$ & - & \\
\hline DDT & 18.059 & $235(237,165)$ & - & Soil contaminant \\
\hline Iprodione & 19.508 & $314(315,316)$ & - & \\
\hline
\end{tabular}


TABle 1: Continued.

\begin{tabular}{|c|c|c|c|c|}
\hline $\begin{array}{l}\text { Pesticide active } \\
\text { ingredient/metabolite }\end{array}$ & $\begin{array}{l}\text { Retention } \\
\text { times } \\
(\min ) \\
\end{array}$ & $\begin{array}{l}\text { Quantitation ion } \\
\text { (other ions) }(m / z)\end{array}$ & $\begin{array}{c}\text { Concentration } \\
\text { range as diffuse } \\
\text { contaminant }(\mathrm{ng} / \mathrm{L}) \\
\end{array}$ & Comment \\
\hline \multicolumn{5}{|c|}{ Acidic substances } \\
\hline MCP tBDMS ${ }^{\mathrm{a}}$ & 7.524 & $199(201,125)$ & - & \\
\hline $\mathrm{DCP}_{\mathrm{tBDMS}}^{\mathrm{a}}$ & 7.957 & $219(221,93)$ & - & \\
\hline Mecoprop tBDMS ${ }^{\mathrm{a}}$ & 9.208 & $225(271,227)$ & $10-15$ & \\
\hline $\mathrm{MCPA} \mathrm{tBDMS}^{\mathrm{a}}$ & 9.453 & $257+229(211)$ & $5-300$ & \\
\hline Dichlorprop tBDMS ${ }^{\mathrm{a}}$ & 9.584 & $245(247,291)$ & $3-200$ & \\
\hline $2,4-\mathrm{D} \mathrm{tBDMS}^{\mathrm{a}}$ & 9.882 & $251+233(279,277,281)$ & $10-1000$ & \\
\hline MCPB tBDMS ${ }^{\mathrm{a}}$ & 10.226 & $281(325,253)$ & $10-20$ & \\
\hline $2,4,5-\mathrm{T}$ tBDMS ${ }^{\mathrm{a}}$ & 10.526 & $285+311(267,75)$ & - & \\
\hline 2,4,5-TP tBDMS ${ }^{\mathrm{a}}$ & 10.648 & $201+199(202)$ & - & \\
\hline 2,4-DB tBDMS ${ }^{\mathrm{a}}$ & 10.910 & $219(201)$ & - & \\
\hline \multicolumn{5}{|c|}{ HPLC analysis } \\
\hline Thiamethoxam & 2.42 & $292(211,246)$ & $4-30$ & \multirow{2}{*}{$\begin{array}{l}10-41 \mu \mathrm{g} / \mathrm{L} \text { measured from temporary } \\
\text { shallow water bodies }\end{array}$} \\
\hline Clothianidin & 3.38 & $250(132,168,169)$ & $17-40$ & \\
\hline \multicolumn{5}{|c|}{ ELISA } \\
\hline Glyphosate & - & - & $500-1000$ & \\
\hline
\end{tabular}

${ }^{a}$ Chlorophenoxy acids and the corresponding phenol metabolites have been determined by a parallel chromatographic method as t-butyldimethylsilyl esters or ethers (tBDMS).

Drift from intensively cultivated fields has been observed, but illegal pesticide use could not be assumed, as most often water pollutants, atrazine, and acetochlor were hardly detected. Trifluralin seems to be persistent in soil under appropriate circumstances and its dissipation is slow. From persistent compounds, the presence of DDT and its decomposition product DDE can be still detected in about half of the Hungarian soils at very low levels, and they exert a long term effect.

Our results confirmed that ecological fields could be contaminated via irrigation water; therefore, it should also be monitored especially in corn cultivation regions. Although withdrawal of some water pollutants (atrazine in 2007, diazinon in 2008 and trifluralin in 2009) probably improved water quality, the use of certain water resources as irrigation water in ecological farming should/has to be restricted.

As it was observed later in project MONTABIO, withdrawal of the above mentioned ingredients resulted in their gradual disappearance. Atrazine could be detected only in samples collected at Gyomaendrőd in 2010, while earlier it had been detected in samples from Békéscsaba and Orosháza. Trifluralin often detected as a soil pollutant has, due to its limited water solubility, quite long dissipation time. Therefore, it could be detected in water samples in all years between 2008 and 2010. Diazinon was often found in water samples collected in 2008, not detected in 2009, but in 2010 eight ground water samples contained this insecticide. They appeared even in 2011; thus their dissipation is slow.

Frequent occurrence and temporarily high levels of acetochlor, as well as metolachlor, might be related to their use instead of atrazine in Hungary. Detections of acetochlor in surface water probably contributed to its withdrawal in EU in 2012. The temporal pollution "plaques" of herbicide residues in rivers upon broad field application of herbicides pollute potential irrigation water sources and pose risk to the drinking water supply. Concentrations of acetochlor and metolachlor reported in this study are comparable to those found in the Danube River basin in Serbia (80 and $150 \mathrm{ng} / \mathrm{L}$ ) [46]. In contrast to this Serbian study terbuthylazine was not detected in our surveys.

Atrazine was used predominantly as herbicide in maize monocultures in Hungary. In contrast to DDT, which was banned first in the world in Hungary in 1968, atrazine was benig used up to the last date possible by derogation measures upon its ban in EU in 2007. It was often detected in the US, for example, in ground water [47] together with other pesticide active ingredients (simazine, metolachlor, etc.). Diazinon insecticide was also banned in 2007. Trifluralin active ingredient is banned in Hungary since 2009; acetochlor used mainly as a herbicide in maize crops was banned in 2012. Some of these compounds are on the list of the 45 priority substances [13]. Atrazine was present at higher levels only in samples belonging to extreme point source contamination. Concentrations at these sites sometimes exceeded the values of $2000 \mathrm{ng} / \mathrm{L}$ established by the legislation as the MAC for atrazine in inland surface waters. Its levels in other water samples were far below the MRL, and upon withdrawal, its levels and occurrence frequency seem to decrease. Trifluralin, which is often detected as a water pollutant in our studies at low concentrations due to its poor water solubility, is also 
listed as priority substance [13], although with no applicable MAC value.

Compared to our findings (19-70 ng/L) lower levels were reported for atrazine $(<5 \mathrm{ng} / \mathrm{L})$ from all parts of Danube in August, 2011 [48], but its metabolite desethylatrazine could be detected at levels 5-20 ng/L with maximum levels around Budapest.

Regarding chlorophenoxy acid type herbicides $2,4-\mathrm{D}$ is one of the most widely used herbicides in the world and mixtures of mecoprop, dichlorprop, and MCPA are often applied. As our results indicate these compounds often occur in surface water and amounts of 2,4-D can be usually quantified (56-186 ng/L in 2011). Similar results have been reported in a study [48] conducted in August and September, 2011, with limited number of target compounds belonging to pesticides. The highest concentrations for 2,4-D were found in the area around Budapest $(\sim 50 \mathrm{ng} / \mathrm{L})$, whereas in the AustrianSlovakian part of the Danube and in the downstream part lower concentrations ( $\sim 20 \mathrm{ng} / \mathrm{L}, \sim 10 \mathrm{ng} / \mathrm{L})$ were measured.

Despite of the fact that glyphosate is the most frequently used herbicide in Hungary, as well as worldwide, there is little known information about its levels in the environment. Due to its fast decomposition and low detectability it is rarely measured. Regarding contamination rates and levels of glyphosate, the great contrast between sampling regimes is explained by differing agricultural locations, and, to a greater extent, catchment area characteristics, resulting in varying leaching or runoff of glyphosate to surface water. Contamination rates and levels found are strongly influenced by amounts of natural precipitation. Glyphosate contamination reported in large scale environmental water contamination studies was similar to our results. Byer et al. [27] analyzed over 700 samples in Canada using an ELISA method. Concentrations were above LOD (100 ng/L) in 33\% of the samples collected in 2007, with peak values (up to $12000 \mathrm{ng} / \mathrm{L}$ ) in late spring/early summer and fall. A monitoring study in Norway [49] found frequent occurrence of glyphosate and AMPA in surface water (54\% of 540 surface water samples in 1995-1999). Monitoring in Catalonia, Spain, between 2007 and 2010 [26], reported a $41 \%$ contamination rate in the ground water samples analyzed. Similar findings were reported in the United States [50, 51], as well as in Canada in 2004-2005 (21\% of 502 samples contained glyphosate or AMPA at very high maximum concentrations of 41 and $30 \mathrm{ng} / \mathrm{mL}$, resp.) [52].

\section{Conclusions}

During this period detectable pesticide residues at low concentrations occurred in alarming proportions of the surface water samples analyzed over decades. Hardly were found samples with pesticide residues below the analytical LOD, even in natural protection or recreational areas. Among monitored pesticides, the most frequently found ingredients are mainly used in maize production. High and periodic herbicide residue levels mostly reflect current herbicide usage, while low to moderate levels of certain pesticides (e.g., trifluralin) indicate a general diffuse contamination countrywide. However, high concentrations observed at point sources were not due to agricultural pesticide application but were related to the pesticide production industry. Contamination levels in ecological fields were substantially lower than that of intensively cultivated fields. However, residues are present in organic cultivation and cause exposure due to persistent organic pollutants (POPs) in soil and due to contamination of irrigation water.

Occurrence of banned ingredients may indicate illegal pesticide use or slow decomposition in the given environmental matrix. Among often detected water pollutants some ingredients (atrazine, diazinon, and trifluralin) have been withdrawn in the meantime that can improve water quality. However, as the obtained results show, these compounds and their residues can still be detected in environmental matrices due to their slow degradation rate.

Observed pesticide residue levels in surface waters correlate with current pesticide applications and rates. The ongoing process of pesticide reevaluation in the EU resulted in reregistration of only $27 \%$ of the authorized pesticide active ingredients between 1995 and 2009 [53]. In turn, the range of available pesticides registered for crop and horticultural plant protection has substantially changed in Hungary after 2004 as the country became a full member of the EU. Among insecticides and acaricides, as well as fungicides and antimicrobials, numerous active ingredients have been withdrawn and replaced by new types (novel pyrethroid, neonicotinoid insecticides, triazole, and strobilurin fungicides). The most radical changes occurred among herbicides that represent over half of the pesticide market. In addition to several thiocarbamates (EPTC, butylate), major triazines (atrazine, cyanazine, terbutryn, and prometryn) and chloroacetamides (propachlor, alachlor, propisochlor, and acetochlor) have been gradually banned. Moreover, the shrinkage in herbicide active ingredients led to the predominance of glyphosate on the herbicide market with over 30 various currently registered glyphosate-based formulations. However, on the basis of the resulting increase in environmental occurrence and exposure routes of glyphosate, as well as its recent classification in Group 2A (probably carcinogenic to humans) by the International Agency for Research on Cancer [54] glyphosate is likely to face restrictions on its use in the near future, which will, in turn, affect its levels in environmental matrices. Certain replacement (and only later banned) compounds (e.g., acetochlor) occurred as surface water contaminants. Thus, main surface water contaminants were triazines (atrazine, propisochlor), chloroacetamides (acetochlor, metolachlor), and phenoxycarboxylic acids (2,4-D, MCPA) during the late nineties, followed by triazines (atrazine, prometryn, and diazinon) and chloroacetamides (acetochlor) after the turn of the millennium, while glyphosate and neonicotinoids are more frequently detected lately with the advancement of analytical techniques.

\section{Disclaimer}

This publication reflects the views only of the authors, and the European Commission cannot be held responsible for any use which may be made of the information contained therein. 


\section{Conflict of Interests}

The authors declare that there is no conflict of interests regarding the publication of this paper.

\section{Acknowledgments}

This work was supported for varying periods by all projects mentioned in the "Results" section. Current financial support is received from projects "Mechanism-Related Teratogenic Hormone Modulant and Other Toxicological Effects of Veterinary and Agricultural Surfactants" (OTKA K109865) and "Identification of Biologically Active Compounds and Their Metabolites of Neurotoxic Effects, Chemical/Ecotoxicological Assessment of Their Effects" (OTKA K112978) of the Hungarian Scientific Research Fund, "Assessment of (Bio)Chemical and Biological Main and Side-Effects of Organic Microcontaminants of Agricultural Origin" (AD006, 2013-2017) of the Hungarian Ministry of Agriculture, and EU-project SPICED (Grant Agreement: 312631) with the financial support from the 7th Framework Programme of the EU.

\section{References}

[1] C. MacBean, Ed., The Pesticide Manual, British Crop Production Council, Brighton, UK, 16th edition, 2015.

[2] H. Aizawa, Metabolic Maps of Pesticides, vol. 1, Academic Press, San Diego, Calif, USA, 1982.

[3] H. Aizawa, Metabolic Maps of Pesticides, vol. 2, Academic Press, San Diego, Calif, USA, 1989.

[4] R. Krieger, Hayes' Handbook of Pesticide Toxicology, Elsevier, London, UK, 3rd edition, 2010.

[5] R. J. Gilliom, J. E. Barbash, G. G. Crawford et al., The Quality of Our Nation's Waters: Pesticides in the Nation's Streams and Ground Water, 1992-2001, US Geological Survey, 2007.

[6] H. S. Rathore and L. M. L. Nollet, Pesticides. Evaluation of Environmental Pollution, CRC Press, Boca Raton, Fla, USA, 2012.

[7] U. Ali, J. H. Syed, R. N. Malik et al., "Organochlorine pesticides (OCPs) in South Asian region: a review," Science of the Total Environment, vol. 476-477, pp. 705-717, 2014.

[8] I. Hanke, I. Wittmer, S. Bischofberger, C. Stamm, and H. Singer, "Relevance of urban glyphosate use for surface water quality," Chemosphere, vol. 81, no. 3, pp. 422-429, 2010.

[9] European Parliament and Council, "Directive 2006/118/EC of 12 December 2006 on the protection of groundwater against pollution and deterioration," Official Journal of the European Union L, vol. 372, pp. 19-31, 2006.

[10] European Parliament and Council, "Council Directive 98/83/ EC of 3 November 1998 on the quality of water intended for human consumption," Official Journal of the European Union, vol. L330, pp. 32-54, 1998.

[11] European Parliament and Council, "Directive 2000/60/EC of the of 23 October 2000 establishing a framework for community action in the field of water policy," Official Journal of the European Union, vol. L327, 2000.

[12] European Parliament and Council, "European Union Directive 2008/105/EC of the European Parliament and of the Council on environmental quality standards in the field of water policy," Official Journal of European Union L, vol. 348, pp. 84-97, 2008.
[13] European Parliament and Council, "Directive 2013/39/EU of 12 August 2013 amending Directives 2000/60/EC and 2008/ $105 / \mathrm{EC}$ as regards priority substances in the field of water policy," Official Journal of the European Union, vol. L226, no. 1, 2013.

[14] R. Loos, G. Locoro, S. Comero et al., "Pan-European survey on the occurrence of selected polar organic persistent pollutants in ground water," Water Research, vol. 44, no. 14, pp. 4115-4126, 2010.

[15] R. Loos, B. M. Gawlik, G. Locoro, E. Rimaviciute, S. Contini, and G. Bidoglio, "EU-wide survey of polar organic persistent pollutants in European river waters," Environmental Pollution, vol. 157, no. 2, pp. 561-568, 2009.

[16] P. Lepom, B. Brown, G. Hanke, R. Loos, P. Quevauviller, and J. Wollgast, "Needs for reliable analytical methods for monitoring chemical pollutants in surface water under the European Water Framework Directive," Journal of Chromatography A, vol. 1216, no. 3, pp. 302-315, 2009.

[17] G. Károly, L. Györfi, and Z. Ocskó, "Surveys of Hungarian surface waters for pesticide contamination," Növényvédelem, vol. 37, pp. 539-545, 2001 (Hungarian).

[18] Z. Kárpáti, L. Győrfi, M. Csanády et al., "Plant protecting agents in drinking water," Egészségtudomány, vol. 42, no. 2, pp. 143-152, 1998 (Hungarian).

[19] E. Maloschik, M. Mörtl, and A. Székács, "Novel derivatisation technique for the determination of chlorophenoxy acid type herbicides by gas chromatography-mass spectrometry," Analytical and Bioanalytical Chemistry, vol. 397, no. 2, pp. 537-548, 2010.

[20] M. Mörtl, G. Németh, J. Juracsek et al., "Determination of glyphosate residues in Hungarian water samples by immunoassay," Microchemical Journal, vol. 107, pp. 143-151, 2013.

[21] E. Majzik-Solymos, É. Visi, G. Károly, B. Beke-Berczi, and L. Györfi, "Comparison of extraction methods to monitor pesticide residues in surface water," Journal of Chromatographic Science, vol. 39, no. 8, pp. 325-331, 2001.

[22] E. Maloschik, A. Ernst, G. Hegedűs, B. Darvas, and A. Székács, "Monitoring water-polluting pesticides in Hungary," Microchemical Journal, vol. 85, no. 1, pp. 88-97, 2007.

[23] M. Küsters and M. J. Gerhartz, "Enrichment and low-level determination of glyphosate, aminomethylphosphonic acid and glufosinate in drinking water after cleanup by cation exchange resin," Journal of Separation Science, vol. 33, no. 8, pp. 1139-1146, 2010.

[24] Abraxis, Glyphosate Plate Kit Part No. 500086, Abraxis LLC, Warminster, Pa, USA, 2005, http://www.abraxiskits.com/uploads /products/docfiles/184_PN500086USER.pdf.

[25] E. Chen, J. Parmar, J. Li et al., "Glyphosate detection in water by enzyme-linked immunosorbent assay (ELISA)," in Proceedings of the 44th Central Canadian Symposium on Water Quality Research, Burlington, Canada, February 2009, http://www .cawq.ca/en/docs/central_symp/044/presentations/EC_E.Chen .pdf.

[26] J. Sanchís, L. Kantiani, M. Llorca et al., "Determination of glyphosate in groundwater samples using an ultrasensitive immunoassay and confirmation by on-line solid-phase extraction followed by liquid chromatography coupled to tandem mass spectrometry," Analytical and Bioanalytical Chemistry, vol. 402, no. 7, pp. 2335-2345, 2012.

[27] J. D. Byer, J. Struger, P. Klawunn, A. Todd, and E. D. Sverko, "Low cost monitoring of glyphosate in surface waters using the ELISA method: an evaluation," Environmental Science and Technology, vol. 42, no. 16, pp. 6052-6057, 2008. 
[28] K. Starner and K. S. Goh, "Detections of the neonicotinoid insecticide imidacloprid in surface waters of three agricultural regions of California, USA, 2010-2011," Bulletin of Environmental Contamination and Toxicology, vol. 88, no. 3, pp. 316-321, 2012.

[29] O. Samson-Robert, G. Labrie, M. Chagnon, and V. Fournier, "Neonicotinoid-contaminated puddles of water represent a risk of intoxication for honey bees," PLoS ONE, vol. 9, no. 12, Article ID e108443, 2014.

[30] J.-M. Bonmatin, C. Giorio, V. Girolami et al., "Environmental fate and exposure; neonicotinoids and fipronil," Environmental Science and Pollution Research, vol. 22, no. 1, pp. 35-67, 2015.

[31] A. Schaafsma, V. Limay-Rios, T. Baute, J. Smith, Y. Xue, and P. Spanoghe, "Neonicotinoid insecticide residues in surface water and soil associated with commercial maize (corn) fields in Southwestern Ontario," PLoS ONE, vol. 10, no. 2, Article ID e0118139, 2015.

[32] A. Székács and B. Darvas, "Forty years with glyphosate," in Herbicides-Properties, Synthesis and Control of Weeds, M. N. E.-G. Hasaneen, Ed., pp. 247-284, InTech, Rijeka, Croatia, 2012.

[33] D. K. Jones, J. I. Hammond, and R. A. Relyea, "Competitive stress can make the herbicide Roundup more deadly to larval amphibians," Environmental Toxicology and Chemistry, vol. 30, no. 2, pp. 446-454, 2011.

[34] A. Paganelli, V. Gnazzo, H. Acosta, S. L. López, and A. E. Carrasco, "Glyphosate-based herbicides produce teratogenic effects on vertebrates by impairing retinoic acid signaling," Chemical Research in Toxicology, vol. 23, no. 10, pp. 1586-1595, 2010.

[35] N. Benachour and G.-E. Séralini, "Glyphosate formulations induce apoptosis and necrosis in human umbilical, embryonic, and placental cells," Chemical Research in Toxicology, vol. 22, no. 1, pp. 97-105, 2009.

[36] P. Laitinen, K. Siimes, L. Eronen et al., "Fate of the herbicides glyphosate, glufosinate-ammonium, phenmedipham, ethofumesate and metamitron in two finnish arable soils," Pest Management Science, vol. 62, no. 6, pp. 473-491, 2006.

[37] I. Székács, Á. Fejes, S. Klátyik et al., "Environmental and toxicological impacts of glyphosate with its formulating adjuvant," International Journal of Biological, Veterinary, Agricultural and Food Engineering, vol. 8, pp. 213-218, 2014.

[38] A. Székács, M. Mörtl, G. Fekete et al., "Monitoring and biological evaluation of surface water and soil micropollutants in Hungary," Carpathian Journal of Earth and Environmental Sciences, vol. 9, no. 3, pp. 47-60, 2014.

[39] E. Paszti-Gere, R. F. Barna, C. Kovago et al., "Changes in the distribution of Type II transmembrane serine protease, TMPRSS2 and in paracellular permeability in IPEC-J2 cells exposed to oxidative stress," Inflammation, vol. 38, no. 2, pp. 775-783, 2015.

[40] R. Mesnage, E. Clair, S. Gress, C. Then, A. Székács, and G.-E. Séralini, "Cytotoxicity on human cells of CrylAb and CrylAc Bt insecticidal toxins alone or with a glyphosate-based herbicide," Journal of Applied Toxicology, vol. 33, no. 7, pp. 695-699, 2013.

[41] D. Goulson, "An overview of the environmental risks posed by neonicotinoid insecticides," Journal of Applied Ecology, vol. 50, no. 4, pp. 977-987, 2013.

[42] V. Girolami, L. Mazzon, A. Squartini et al., "Translocation of neonicotinoid insecticides from coated seeds to seedling guttation drops: a novel way of intoxication for bees," Journal of Economic Entomology, vol. 102, no. 5, pp. 1808-1815, 2009.

[43] L. M. B. Rigueira, K. de L. Ribeiro, M. E. L. R. de Queiroz, A. A. Neves, L. Zambolim, and R. M. Oliveira, "Determination of chlorpyrifos and thiamethoxam in potato tuber (Solanum tuberosum L.) and soil of Brazil using solid-liquid extraction with low temperature partitioning (SLE/LTP)," Journal of the Brazilian Chemical Society, vol. 24, no. 12, pp. 2042-2049, 2013.

[44] M. Chen, L. Tao, J. McLean, and C. Lu, "Quantitative analysis of neonicotinoid insecticide residues in foods: implication for dietary exposures," Journal of Agricultural and Food Chemistry, vol. 62, no. 26, pp. 6082-6090, 2014.

[45] European Parliament and Council, "Commission implementing regulation (EU) no 485/2013," Official Journal of the European Union, vol. L139, 2013, http://eur-lex.europa.eu/LexUriServ/LexUriServ.do?uri=OJ:L:2013:139:0012:0026:EN:PDF.

[46] N. Antić, M. Radišić, T. Radović et al., "Pesticide residues in the Danube River Basin in Serbia-a survey during 2009-2011," CLEAN-Soil, Air, Water, vol. 43, no. 2, pp. 197-204, 2015.

[47] P. J. Squillace, J. C. Scott, M. J. Moran, B. T. Nolan, and D. W. Kolpin, "VOCs, pesticides, nitrate, and their mixtures in groundwater used for drinking water in the United States," Environmental Science and Technology, vol. 36, no. 9, pp. 19231930, 2002.

[48] R. Loos, G. Locoro, and S. Contini, "Occurrence of polar organic contaminants in the dissolved water phase of the Danube River and its major tributaries using SPE-LC-MS ${ }^{2}$ analysis," Water Research, vol. 44, no. 7, pp. 2325-2335, 2010.

[49] G. H. Ludvigsen and O. Lode, "Results from the agricultural and environmental monitoring program of pesticides in Norway 1995-1999," Fresenius Environmental Bulletin, vol. 10, pp. 470474, 1995.

[50] D. W. Kolpin, E. M. Thurman, E. A. Lee, M. T. Meyer, E. T. Furlong, and S. T. Glassmeyer, "Urban contributions of glyphosate and its degradate AMPA to streams in the United States," Science of the Total Environment, vol. 354, no. 2-3, pp. 191-197, 2006.

[51] E. A. Scribner, W. A. Battaglin, R. J. Gilliom et al., "Concentrations of glyphosate, its degradation product, aminomethylphosphonic acid, and glufosinate in ground- and surface-water, rainfall, and soil samples collected in the United States, 2001-06," U.S. Geological Survey Scientific Investigations Report 20075122, U.S. Department of the Interior, U.S. Geological Survey, Reston, Va, USA, 2007, http://pubs.usgs.gov/sir/2007/5122/.

[52] J. Struger, D. Thompson, B. Staznik, P. Martin, T. McDaniel, and C. Marvin, "Occurrence of glyphosate in surface waters of southern Ontario," The Bulletin of Environmental Contamination and Toxicology, vol. 80, no. 4, pp. 378-384, 2008.

[53] A. Anton, G. Fekete, B. Darvas et al., "Environmental risk of chemical agriculture," in Engineering Tools for Environmental Risk Management. Vol. 1. Environmental Deterioration and Contamination-Problems and Their Management, K. Gruiz, T. Meggyes, and E. Fenyvesi, Eds., pp. 93-112, CRC Press, Boca Raton, Fla, USA, 2014.

[54] IARC, Glyphosate, vol. 112 of IARC Monographs, International Agency for Research on Cancer (IARC), Lyon, France, 2015, http://monographs.iarc.fr/ENG/Monographs/voll12/monol1202.pdf. 

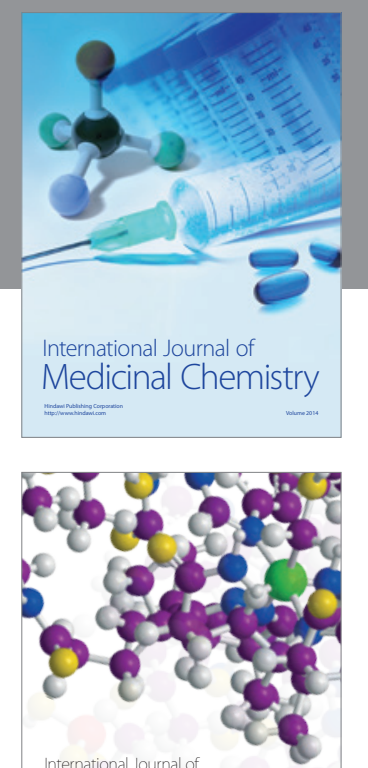

\section{Carbohydrate} Chemistry

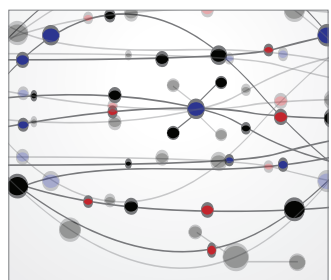

The Scientific World Journal
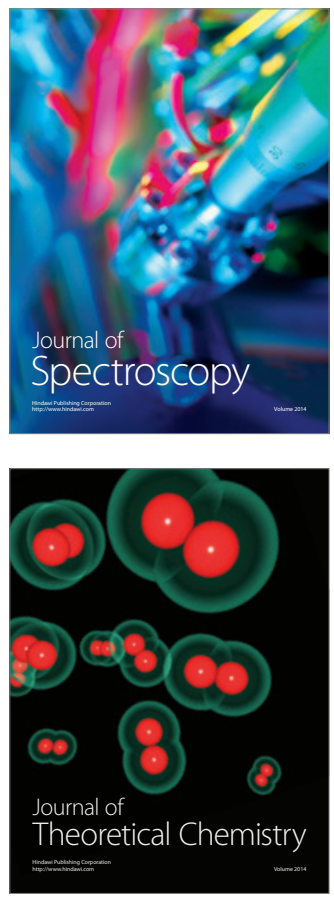
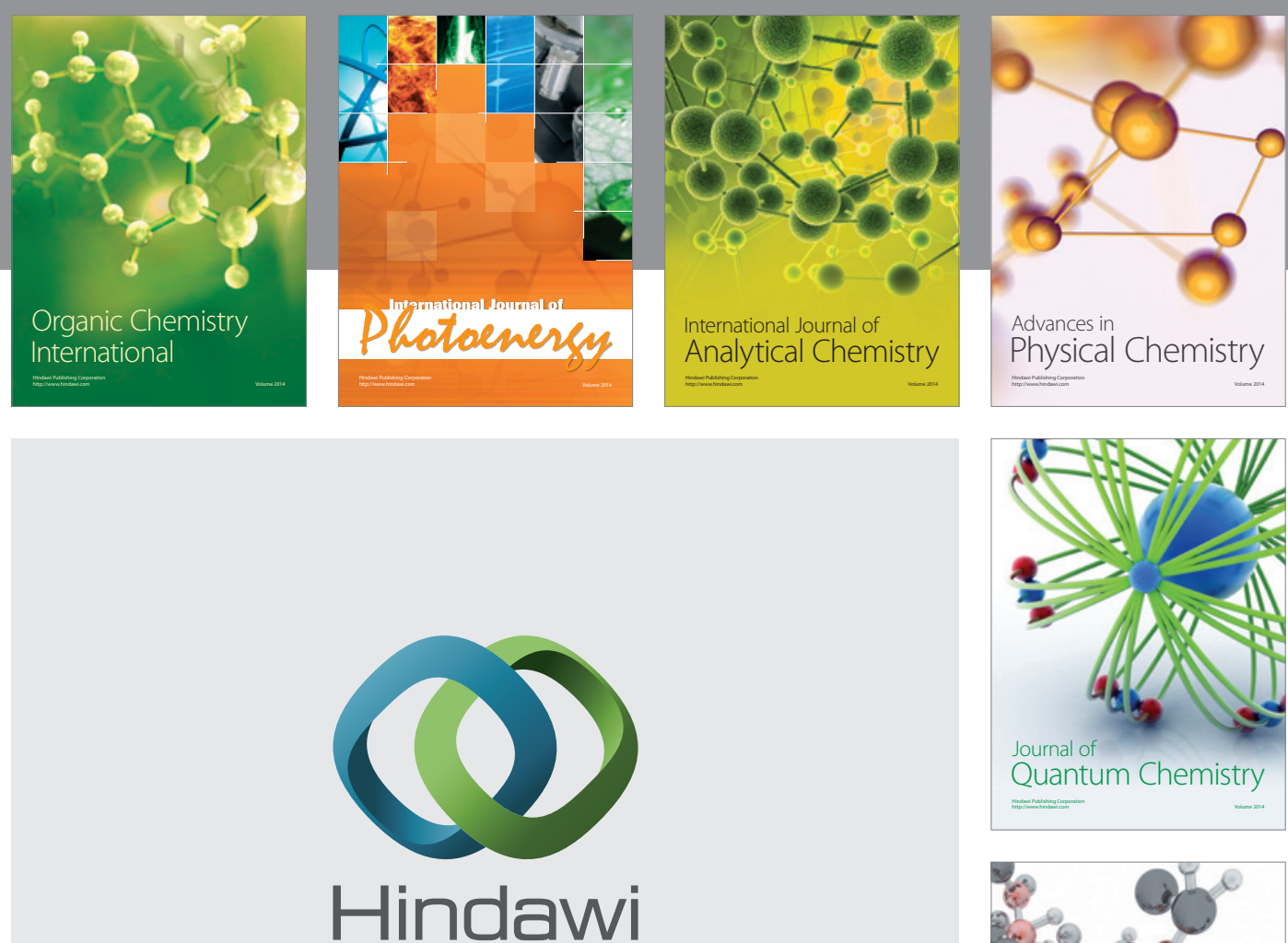

Submit your manuscripts at

http://www.hindawi.com

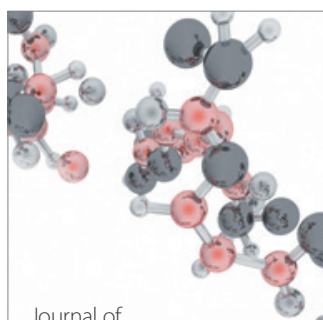

Analytical Methods

in Chemistry

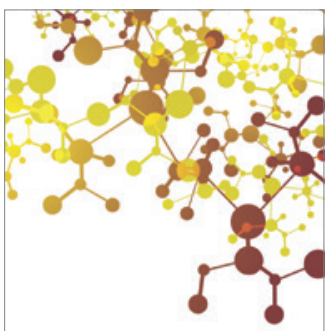

Journal of

Applied Chemistry

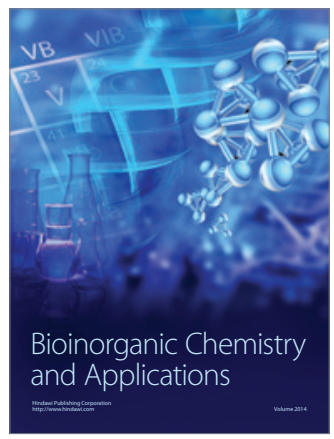

Inorganic Chemistry
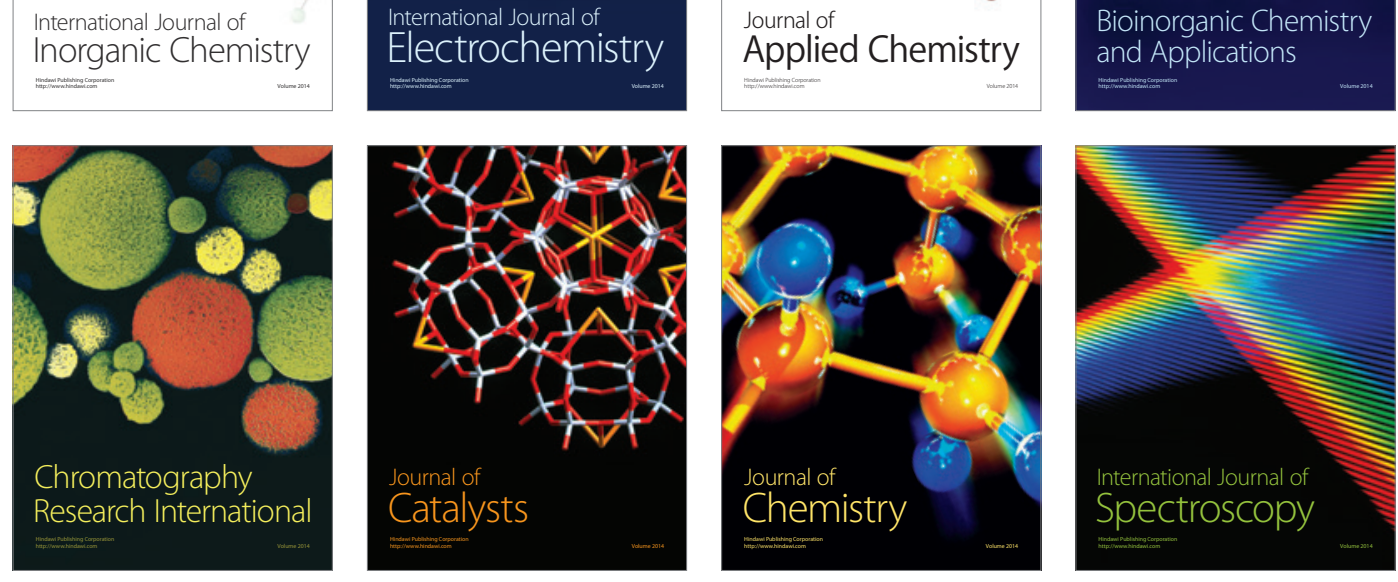